\title{
FIRST DOCUMENTED RECORD OF THE BAND-TAILED PIGEON IN SASKATCHEWAN
}

CHRISTOPHER I.G. ADAM, 2636 Argyle Street, Regina, Saskatchewan, S4S OK1 and ROBERT KREBA, Saskatchewan Museum of Natural History, Wascana Park, Regina, Saskatchewan. S4P 3V7

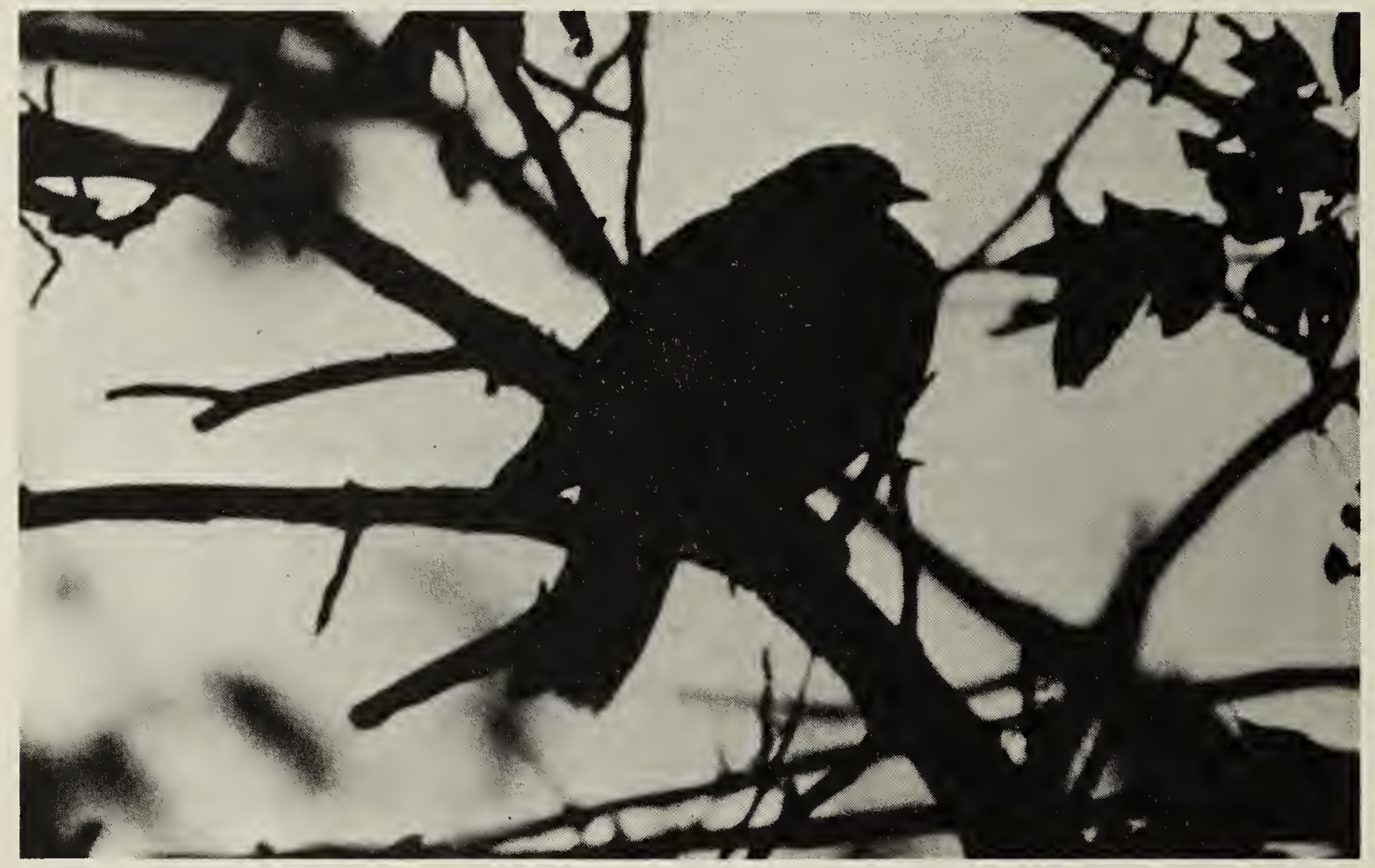

Band-tailed Pigeon at Weyburn, Saskatchewan

Chris Escott

In Canada the Band-tailed Pigeon is normally found in the open mixedwood forests of coastal British Columbia. ${ }^{1}$ Despite this, it does sometimes wander inland, and has been reported in Saskatchewan on several occasions since $1970 .^{2} 3456$ 7 None of these records had been substantiated by a photograph or a specimen, leaving the Band-tailed Pigeon as a hypothetical species on the 1984 field checklist of Saskatchewan birds. In late summer of 1984, an adult bird of this species stayed at Weyburn for almost two weeks, during which time it was seen by numerous photographed.

The Band-tailed Pigeon is superficially very similar to the domestic Rock Dove, although it is slightly larger. Weyburn resident Nick Postey first noticed a "strange" pigeon on the grounds of the Souris Valley Extended Care Hospital on 24 August. It did not associate with the numerous Rock Doves and spent most of its time in trees or bushes. $\mathrm{He}$ was able to observe it well enough to identify it as an adult Band-tailed Pigeon; he subsequently showed it to Ray Belanger and others. 
Realizing that the bird was out of its usual range, Postey telephoned Bob Luterbach, in Regina on 25 August. The pigeon was not seen on the 26th, but reappeared on the 27th in a large poplar it had evidently selected for its evening roost. On 28 August, C. Adam, F. Brazier, R. Kreba and $B$. Luterbach travelled from Regina to meet Postey and Belanger at Weyburn hoping to see the bird.

In the late afternoon the pigeon was flushed from a tall caragana hedge near the roost tree. Observed briefly as it flew, four characteristics noted were large size, gray body, absence of white on rump, and a banded tail. Other diagnostic features observed while the bird perched in the roost tree were the white band on nape, black-tipped yellow bill, and yellow feet. The banded tail is a poor field mark that is not readily observable.

The pigeon was studied for almost an hour with binoculars and tripodmounted scopes (up to 60X). During this time, Chris Adam obtained several identifiable photos of the pigeon, using a $70-250 \mathrm{~mm}$ zoom lens, thus documenting the sighting for the provincial list.

The pigeon remained in the tree when the observers left shortly before dusk. According to Postey, the bird returned to this roost tree every evening until it was last observed 4 September. It could not be found during the day when it was presumably foraging elsewhere. Postey also noted that on 5 September, not only did the Bandtailed Pigeon fail to appear in its usual roost tree, but that the regular population of Mourning Doves had also departed the area.

Postey was able to show the Bandtailed Pigeon to Saskatoon birders A. Smith, C. Escott and H. Lane on 1
September; identifiable colour slides were also obtained by Escott. Both Adam and Escott donated copies of these to the photographic files of the Museum of Natural History in Regina.

Previous sightings of the Bandtailed Pigeon in Saskatchewan have always been of single birds, usually seen briefly over one or two days by only one or two observers. These records were 6 August, 1970, at Valley Centre near Rosetown, by Wayne and Don Renaud, 30 September, 1970, at Saskatoon, by Shelagh Aldous, 28-29 June, 1980, near Mortlach, by B. Forbes, 20-21 June, 1981 near Herbert (about $80 \mathrm{~km}$ west of the 1980 sighting), also by B. Forbes, and 25, 28 June, 1982, near Raymore, by W. Harris. ${ }^{6} 7234$

In contrast, the bird at Weyburn was present for 12 days, was at an established roosting site and was tame enough to allow it to be photographed. The Weyburn sighting thus constitutes the sixth record for Saskatchewan, and is the first to be documented by photographs.

'GODFREY, W.E. 1966. The birds of Canada. National Museums of Canada, Ottawa.

${ }^{2}$ GOLLOP, B. 1980. Prairie provinces region. American Birds 34:905.

${ }^{3}$ GOLLOP, B. 1981. Prairie provinces region. American Birds 35:950-952.

${ }^{4}$ GOLLOP, J.B. 1982. Prairie provinces region. American Birds 36:988-990.

${ }^{5}$ HOUSTON, C.S., M.I. HOUSTON and J.B. GOLLOP. 1981. Saskatchewan bird species - hypothetical and rejected. Blue Jay 39:196-201.

${ }^{6}$ RENAUD, W. 1970 . First sight record of the Band-tailed Pigeon in Saskatchewan. Blue Jay 28:166.

'SHADICK, S. 1975. Highlights of Saskatoon bird observations $1970-1974$. Blue Jay 33:165-168. 